\title{
Role of Undergraduate Medical Students in Designing Teaching Module in Anatomy for Effective Learning
}

\author{
Preeti Prabhakarrao Thute ${ }^{1}$, Sunita Jayant Vagha ${ }^{2}$ \\ ${ }^{1}$ Department of Anatomy, Jawaharlal Nehru Medical College, Sawangi (Meghe), Wardha, Maharashtra, \\ India. ${ }^{2}$ Department of Pathology, Jawaharlal Nehru Medical College, Sawangi (Meghe), Wardha, Maharashtra, India.
}

\section{ABSTRACT}

\section{BACKGROUND}

The importance of the students in the development of the medical curriculum has been very well known. The valuable perspective and insight of the medical students is very essential in the development of new student-centred teaching modules with student friendly methodology, tools and learning resource materials to increase students' interest improving their understanding and competence in anatomy and eventually create better doctors and for better patient outcomes. In view of this, an interventional study was carried out to study the role of undergraduate medical students in designing teaching module in anatomy for effective learning.

\section{METHODS}

An interventional study was carried out from October 2019 to March 2020 in the Department of Anatomy, Jawaharlal Nehru Medical College Sawangi (Meghe), Wardha. 230 first MBBS students and 50 students i.e., 25 students from each $2^{\text {nd }}$ MBBS and $3^{\text {rd }}$ MBBS participated voluntarily. A routine didactic lecture was conducted for first year MBBS students. Perception was taken with the structured proforma (using Likert scale) from all the students and data analysis was done. A panel was formed with 50 volunteered students from $2^{\text {nd }}$ MBBS and $3^{\text {rd }}$ MBBS who were given responsibility to form module (instructions for the teacher). Then lecture was again conducted for the first year MBBS students incorporating the instructions from the module framed after considering input from data analysis of perception of first MBBS students and from panel of second MBBS and third MBBS students. The data was analysed statistically, using descriptive and inferential statistics using chisquare test. Software used in the analysis were Statistical Package for the Social Sciences (SPSS) 24.0 version and GraphPad Prism 7.0 version.

\section{RESULTS}

After data analysis, it was observed that after implementation of instructions from module there was improvement in all parameters of teaching learning methodology, tools used and learning resource material. The difference was statistically significant.

\section{CONCLUSIONS}

It is evident from the present study that when the teaching learning methodology, teaching learning tools and learning resource materials are designed considering the inputs from the techno savvy students, it is accepted and beneficial for effective learning while still keeping a tinge of the traditional methodology.

\section{KEY WORDS}

Challenges, Criticism, Inputs, Teaching Learning Methodology
Corresponding Author: Dr. Preeti Prabhakarrao Thute, Tathastu, Infront of Ajit Sunder Palace Apartment, Laxminagar, Wardha, Maharshtra - 442001, India. E-mail: b_bakane@rediffmail.com

DOI: 10.14260/jemds/2021/156

How to Cite This Article:

Thute PP, Vagha SJ. Role of undergraduate medical students in designing teaching module in anatomy for effective learning. J Evolution Med Dent Sci 2021;10(10):729734, DOI: 10.14260/jemds/2021/156

Submission 12-10-2020,

Peer Review 17-01-2021,

Acceptance 23-01-2021,

Published 08-03-2021.

Copyright (C) 2021 Preeti Prabhakarrao Thute et al. This is an open access article distributed under Creative Commons Attribution License [Attribution 4.0 International (CC BY 4.0)] 


\section{BACKGROUND}

Among medical academic courses, anatomy teachers are presently facing many of the most intimidating teaching and learning difficulties. ${ }^{1}$ Globally the medical curriculum has been undergoing advancements due to which different approaches of effective teaching are also implemented worldwide. Students are increasingly becoming more technology dependent. Students are also losing interest due to lack of encouragement, prior experience, potential and overloaded with non-academic activities, tight deadlines and financial pressures. $^{2}$ Hence, the teaching responsibility in tertiary education is being changed from merely delivering guidance to maximize student learning, which forces the faculty to evolve learner centred teaching strategies. ${ }^{3}$ It is also important that the instructor should know the needs of the learner and plan learning strategies that are appropriate to those needs. The learner, with the instructor serving as a facilitator, should be consciously engaged in learning. The instructor should understand that different students have different styles of learning and should adapt teaching in distinctive ways adults tend to remember. ${ }^{4}$ The system of medical education needs to adapt itself to the rapid changes taking place in the area of medical science and health care. We need to move away from traditional, teacher-centred, content-oriented mode of education to the student-centred and outcome-oriented medical education system. ${ }^{5}$

The knowledge of different learning strategies is important for both the medical teachers and the learners. The learners identify their learning preferences, which can help them in using the appropriate learning strategies and as a result, they are more likely to become lifetime self-directed learners to maximize their true potential. The teachers become aware of the students' learning styles and they can therefore inculcate those teaching-learning strategies which are tailored to meet the students' learning preferences. This would not only create an effective learning atmosphere, but students would also be encouraged to achieve academic excellence. ${ }^{6}$ As highlighted by the General Medical Council, efficient training methods are now a necessity for medical professionals. ${ }^{7}$ Reforms in undergraduate instruction are thus the need of the hour. It is widely accepted that it is essential to review the teaching curriculum at periodic intervals and to modify the methodologies for imparting basic information.

According to Mark Terrell, educational psychology is well guaranteed to help anatomy teachers to develop creative educational designs that embody existing ideas of best practice while meeting growing pedagogical obstacles and changes in mission paradigm shift. The core element of educational development must be empirical research on the effect of educational advances on students' performance. It is therefore a challenge for educators in anatomy to design and evaluate new instructional methods in anatomy teaching to produce verified and validated practices. ${ }^{8}$

The importance of the student in the development of the medical education has been well described. The advantage of the learners' perspective in curriculum design and development has been endorsed to by administrators, medical instructors, and students alike. Huppatz C explained how students' interventions can make 'consumer-friendly program.., 10 Indeed, it is fair that students are best qualified to give input on the basis of their first-hand understanding of the program and their perception of what it is like to be a student at a certain point in time. ${ }^{8}$

The curriculum modifications are customised to the unique interests of the medical institution, its students, community and national and global needs, enabling specialisation areas to be expanded and missing elements to be filled in. As the curriculum is individually designed, so will be the modifications. The program can become more studentfriendly by constantly revising the teaching materials and new innovative programs run by students under the supervision of faculty members, and can therefore evolve every year. Medical students may be an innovative resource in a medical college as they have a range of perspectives and experiences, and have ideas that are beyond the traditional academic box. ${ }^{11}$

As an instructional planner, they will share their thoughts about how to teach. Input and insight of the younger medical students who are more familiar with technology will become highly important. In addition, engaging students in creating new instructional resources and ideas about how to educate so that their knowledge and skills can be refined eventually to create better doctors with better treatment outcomes. This research was therefore undertaken with 'student friendly learning resources' to improve 'student friendly teaching methods. Hence this study was undertaken to develop 'student friendly teaching' with 'student friendly learning resource material'.

\section{METHODS}

This study was conducted for a duration of 6 months (October 2019 to March 2020). It was an interventional study. First year, second year and final year undergraduate medical students who had given consent were included in the study. First year MBBS students absent on the day of feedback, second year and final year undergraduate medical students who had not given consent to participate were excluded from the study. A total of 230 students were included in this study. First year MBBS students presented on the day of feedback plus 50 students i.e., 25 students from each $2^{\text {nd }}$ MBBS and $3^{\text {rd }}$ MBBS who volunteered to be a part of input group. Sampling \& randomisation was done by complete enumeration technique.

\section{Data Collection Method}

Approval for the research was taken from IEC (institutional ethical committee). Consent was taken from all the participants. A routine didactic lecture was conducted for first year MBBS students of Jawaharlal Nehru Medical College Sawangi (Meghe) Wardha. Perception was taken with the structured proforma (using Likert scale) from all the students regarding traditional teaching learning methodology, teaching learning tool and learning resource material used with the structured proforma and data analysis was done. 50 students i.e., 25 students each from $2^{\text {nd }}$ MBBS and $3^{\text {rd }}$ MBBS who volunteered to participate gave perception about traditional teaching learning methodology, teaching learning tool and learning resource material with which they were taught anatomy. A panel was formed with 50 volunteered students from $2^{\text {nd }}$ MBBS and $3^{\text {rd }}$ MBBS who were given responsibility of 
1. sharing their ideas regarding how to teach (students must think how they learn and actually translate it into the instructions to the teacher in the form of module which also included the results of data analysis of first feedback of first MBBS students for the necessary changes in way of dispensing knowledge and the teaching learning tool used).

2. designing the learning resource material (students must think about how quickly they understand and convert it into the real creation of new learning materials by editing the teacher's content).

Then lecture was again conducted for first year MBBS students incorporating the instructions from the module framed after considering input from data analysis of perception of first MBBS students and from panel of second MBBS and third MBBS students.

\section{Statistical Analysis}

Data was analysed statistically by using descriptive and inferential statistics using chi-square test. The software used in the analysis were Statistical Package for the Social Sciences
(SPSS) 24.0 version and GraphPad Prism 7.0 version and $\mathrm{P}<$ 0.05 was considered as level of significance.

\section{RESULTS}

The students' perception regarding teaching learning methodology, teaching learning tool and learning resource material before and after implementation of the module (instructions) is tabulated in Table 1 and Table 2.

Before implementation of module, maximum number (23 to $31 \%$ ) of students responded neutrally followed by agree and strongly agree except for speed, time allotted for the topic, and use of videos in PowerPoint presentation (PPT) about which maximum students strongly disagreed. After implementation of instruction module, more than $90 \%$ of the students found to be strongly agreed and agreed with the changes made in teaching learning methodology, teaching learning tool and learning resource material. After implementation of module, there was improvement in all parameters of teaching learning methodology, tools used and learning resource material. The difference was statistically significant. (Table 3)

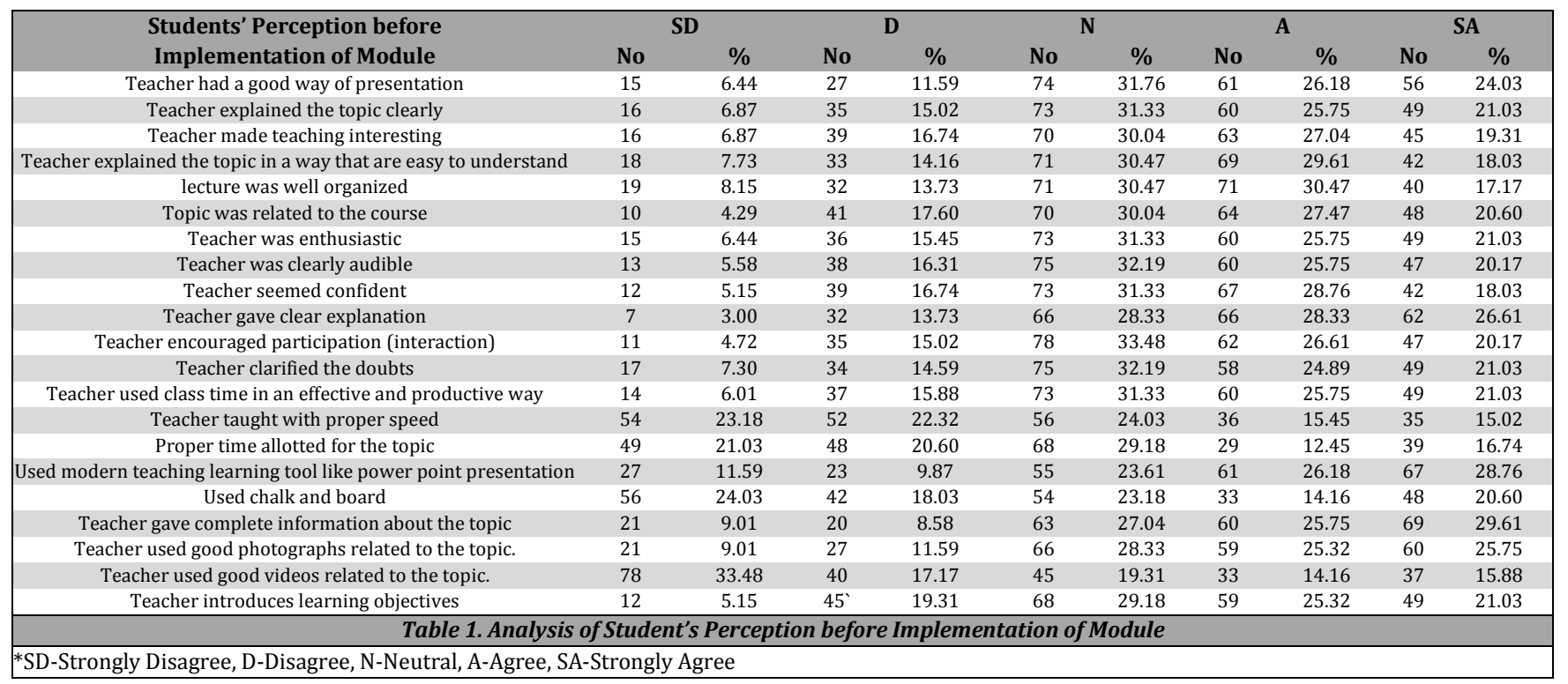

\begin{tabular}{|c|c|c|c|c|c|c|c|c|c|c|}
\hline \multirow{2}{*}{$\begin{array}{l}\text { Student's Perception after } \\
\text { Implementation of Module }\end{array}$} & \multicolumn{2}{|c|}{ SD } & \multicolumn{2}{|c|}{ D } & \multicolumn{2}{|c|}{$\mathbf{N}$} & \multicolumn{2}{|c|}{ A } & \multicolumn{2}{|c|}{ SA } \\
\hline & No & $\%$ & No & $\%$ & No & $\%$ & No & $\%$ & No & $\%$ \\
\hline Teacher had a good way of presentation & 0 & 0.00 & 7 & 3.00 & 0 & 0.00 & 117 & 50.21 & 109 & 46.78 \\
\hline Teacher explained the topic clearly & 0 & 0.00 & 3 & 1.29 & 2 & 0.86 & 120 & 51.50 & 108 & 46.35 \\
\hline Teacher made teaching interesting & 0 & 0.00 & 6 & 2.58 & 3 & 1.29 & 124 & 53.22 & 100 & 42.92 \\
\hline Teacher explained the topic in a way that are Easy to understand & 0 & 0.00 & 2 & 0.86 & 1 & 0.43 & 128 & 54.94 & 102 & 43.78 \\
\hline lecture was well organized & 0 & 0.00 & 1 & 0.43 & 1 & 0.43 & 131 & 56.22 & 100 & 42.92 \\
\hline Topic was related to the course & 0 & 0.00 & 1 & 0.43 & 0 & 0.00 & 122 & 52.36 & 110 & 47.21 \\
\hline Teacher was enthusiastic & 0 & 0.00 & 5 & 2.15 & 1 & 0.43 & 118 & 50.64 & 109 & 46.78 \\
\hline Teacher was clearly audible & 0 & 0.00 & 6 & 2.58 & 2 & 0.86 & 109 & 46.78 & 116 & 49.79 \\
\hline Teacher seemed confident & 0 & 0.00 & 6 & 2.58 & 3 & 1.29 & 116 & 49.79 & 108 & 46.35 \\
\hline Teacher gave clear explanation & 0 & 0.00 & 1 & 0.43 & 1 & 0.43 & 93 & 39.91 & 138 & 59.23 \\
\hline Teacher encouraged participation (interaction) & 0 & 0.00 & 3 & 1.29 & 2 & 0.86 & 113 & 48.50 & 115 & 49.36 \\
\hline Teacher clarified the doubts & 0 & 0.00 & 3 & 1.29 & 1 & 0.43 & 108 & 46.35 & 121 & 51.93 \\
\hline Teacher used class time in an effective and productive way & 0 & 0.00 & 3 & 1.29 & 4 & 1.72 & 116 & 49.79 & 110 & 47.21 \\
\hline Teacher taught with proper speed & 0 & 0.00 & 1 & 0.43 & 1 & 0.43 & 117 & 50.21 & 114 & 48.93 \\
\hline Proper time allotted for the topic & 0 & 0.00 & 6 & 2.58 & 2 & 0.86 & 107 & 45.92 & 118 & 50.64 \\
\hline Used modern teaching learning tool like power point presentation, video & 0 & 0.00 & 2 & 0.86 & 1 & 0.43 & 110 & 47.21 & 120 & 51.50 \\
\hline Used chalk and board & 0 & 0.00 & 2 & 0.86 & 0 & 0.00 & 108 & 46.35 & 123 & 52.79 \\
\hline Teacher gave complete information about the topic & 0 & 0.00 & 0 & 0.00 & 0 & 0.00 & 107 & 45.92 & 126 & 54.08 \\
\hline Teacher used good photographs related to the topic. & 0 & 0.00 & 1 & 0.43 & 0 & 0.00 & 104 & 44.64 & 128 & 54.94 \\
\hline Teacher used good videos related to the topic. & 0 & 0.00 & 0 & 0.00 & 0 & 0.00 & 128 & 54.94 & 105 & 45.06 \\
\hline Teacher introduces learning objectives & 0 & 0.00 & 4 & 1.72 & 1 & 0.43 & 103 & 44.21 & 125 & 53.65 \\
\hline \multicolumn{11}{|c|}{ Table 2. Analysis of Students' Perception after Implementation of Module } \\
\hline
\end{tabular}




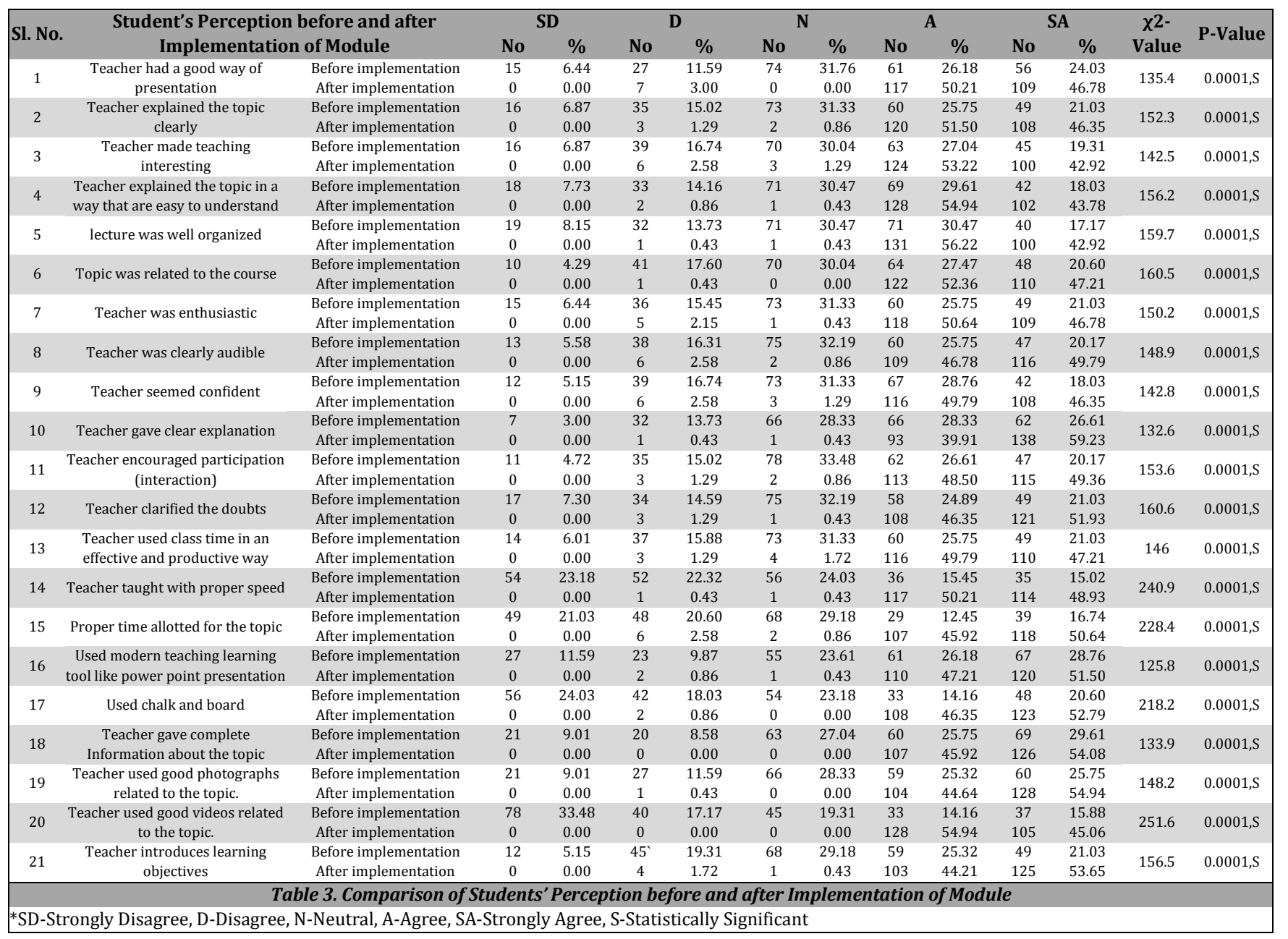

\section{DISCUSSION}

Every teacher is having his / her unique teaching style so do the students have their unique way of learning i.e., grasping the topic. In the middle of major transformations in the 21st century, medical education faces a variety of challenges. ${ }^{12}$

Students put all of their focus on the teacher in teachercentred education. The instructor / teacher speaks, while the students strictly listen. The classroom stays organized. Students remain silent, and the teacher keeps the classroom and its events under full control. As the teacher guides all classroom events, the students don't have to fear that they will miss an important lesson. The predominant figure of authority in this model is teacher. The primary task of teachers is to pass on knowledge and facts to their students. Irby in his research paper gave importance not only to teaching but also to learning. The new requirement is the development of an atmosphere in which students can learn easily and efficiently. Teachers need not only be professionals in their disciplines, but also, and most importantly, they should consider the point on how students learn. ${ }^{13}$

Teaching is not only a transfer of knowledge from an instructor to the learner, but also a two-way system of exchanging ideas and emotions. Teaching is a mechanism that makes learning easy by enabling learners to think, feel and do things. The teacher's usual task has been to serve as a source of knowledge and convey this to the students. To make the learners well versed in the subject, the instructor must connect with the students using appropriate teaching methods. Innovation is still important in the present teaching strategies.

The teacher should play a significant role for the all-round growth of the student by proper teaching methods. For learners, an instructor is a model. If the instructor welcomes students' critique, he will be successful. ${ }^{14}$

There is an old saying that "practice makes man perfect," researchers have found that practice alone does not always lead to success, but constant performance evaluation is necessary for this perfection process. Self-evaluation includes asking questions like "what did the learners learn?" or "how did I performed?" and "how well the learner was able to digest the information". 15

In view of this, the study was conducted to determine the learner's perception and their criticism about the teaching learning methodology of the teacher and their way of learning anatomy using structured proforma among $1^{\text {st }}$ M.B.B.S. students at Sawangi (Meghe) Wardha.

In this study it was observed that more than $50 \%$ of the students opined that the teacher very well introduced the topic and SLO's (specific learning objectives) to the student. This is very important aspect in teaching learning methodology (T-L methodology) under competency-based medical education (CBME) as it is known that the specific learning objectives are the statements which ought to be achieved by the teachers and the students as a part of classroom learning process. 
In this study, it was found that more than $50 \%$ students were having opinion that the teacher used the class time in efficient and productive manner. The findings of this study were consistent with those reported by Ved Prakash et al. ${ }^{16}$

According to our study, $78 \%$ students opined that the teacher used the modern aid like PowerPoint presentation for the didactic lecture which is in accordance with the study reported by Singh et al. who explained that the basic aim of education must be to lead students towards lifelong selfdirected learning which can be achieved through the use of audio-visual aids as it improves the learning capacities of individual students i.e. learning experience that is worth memorable. ${ }^{17}$

In this study, $60 \%$ students opined that the teacher used combination i.e. PowerPoint presentation with chalk and board. The findings of this study were consistent with the findings of Giri P.A. et al. ${ }^{18}$

After the implementation of module, a positive change in the students' perception was recorded about the teacher's way of presentation, improved clarity, proper ways that are easy to understand, proper clear explanation, interactive, with efficient and productive utilisation of time, clarification of doubts, speed of explanation and proper allotment of time. In addition to teaching learning methodology, there were positive perceptions regarding teaching learning tools and the learning resource material used after implementation of module. These results were similar to the results of Ved Prakash et al. ${ }^{16}$

\section{CONCLUSIONS}

In the present study, before implementation of module, $23 \%$ to $31 \%$ students agreed for use of most of the strategies of the traditional teaching and after implementation of module, more than $91 \%$ accepted that the newly designed teaching modalities were more learner centred. Thus, it is evident from the present study that when the teaching learning methodology, teaching learning tools and learning resource materials are designed considering the inputs from the techno savvy students, it is more acceptable and beneficial for effective learning while still keeping a tinge of the traditional methodology.

\section{Limitations}

Inclusion of a small portion of the curriculum of first year was the limitation of the study.

\section{Recommendations}

1. Extended study should be done including larger portion of the curriculum in anatomy and other subjects.

2. In the present scenario we should change from traditional, teacher centred to student centred teaching strategy.

3. The teachers should accept positive criticism from today's techno savvy learners who will definitely act as instructional designers and their positive criticism will enhance the teaching skills of the teachers and help the teachers to develop and analyse new instructional practices for generating verified and validated practices in anatomy according to students' learning styles.

Data sharing statement provided by the authors is available with the full text of this article at jemds.com.

Financial or other competing interests: None.

Disclosure forms provided by the authors are available with the full text of this article at jemds.com.

\section{REFERENCES}

[1] Barr RB, Tagg J. From teaching to learning- a new paradigm for undergraduate education. Change 1995;27:13-25.

[2] Miller SA, Perrotti W, Silverthorn D, et al. From college to clinic: reasoning over memorization is key for understanding anatomy. The Anatomical Record 2002;269(2):69-80.

[3] Reidenberg JS, Laitman JT. The new face of gross anatomy. Anat Rec 2002;269(2):81-8.

[4] King A. From sage on the stage to guide on the side. Coll Teaching 1993;41(1):30-5.

[5] Kulkarni P, Pushpalatha K, Bhat D. Medical education in India: past, present and future. APIK Journal of Internal Medicine 2019;7(3):69-73.

[6] Kharb P, Samanta PP, Jindal M, et al. The learning styles and the preferred teaching-learning strategies of first year medical students. J Clin Diagn Res 2013;7(6):108992.

[7] General Medical Council. Tomorrow's doctors. General Medical Council 2003.

[8] Terrell M. Anatomy of learning: instructional design principles for the anatomical sciences. Anat Rec Part B New Anat 2006;289(6):252-60.

[9] Eichna LW. Medical- school education, 1975-1979: a student's perspective. N Engl J Med 1980;303(13):72734.

[10] Huppatz C. The essential role of the student in curriculum planning. Med Educ 1996;30(1):9-13.

[11] Rosenbaum BP, Gorrindo TL, Patel SG, et al. Medical student involvement in website development. Med Teach 2009;31(7):627-33.

[12] Torre DM, Daley BJ, Sebastian JM, et al. Overview of current learning theories for medical educators. Am J Med 2006;119(10):903-7.

[13] Irby DM. What clinical teachers in medicine need to know. Acad Med 1994;69(5):333-42.

[14] Guilbert JJ. Educational Handbook for Health Personnel. Shahdara: CBS Publishers \& Distributors 1991.

[15] Sumera A. Large group teaching: an effective and efficient teaching methodology. Journal of Asian Scientific Research 2014;4(1):1-5.

[16] Prakash V, Mishra PP. Perceptions of medical students regarding teaching-learning methods adopted by faculty members in Microbiology. International Journal of Medical Science and Education 2016;3(4):338-44.

[17] Singh Y, Sharma T, Upadhya B. Educational technology: teaching and learning. New Delhi (India): APH Publishing Corporation 2008: p. 1-2. 
[18] Giri PA, Phalke DB. Views regarding use of audiovisual aids during didactic lectures in community medicine among first year medical students of rural medical college, Loni, Maharashtra. Nat J Res Comm Med 2013;2(2):145-8. 